\title{
Potensi ekstrak akar Eceng Gondok (Eichhornia crassipes) terhadap buah dan biji Cabai Rawit (Capsicum frutescents L.)
}

\author{
Potential extract of root (Eichhornia crassipes) on fruit and Chili seeds (Capsicum \\ frutescents $L$.)
}

\author{
Vivin Andriani \\ Universitas PGRI Adi Buana Surabaya, Corespondent email: v.andriani@unipasby.ac.id
}

Received: 6 March 2020 | Accepted: 28 June 2020 | Published: 20 July 2020

\begin{abstract}
Abstrak. Penelitian ini bertujuan untuk mengeksplorasi pengaruh ekstrak akar eceng gondok (Eichhornia crassipes) terhadap hasil panen dan jumlah biji cabai rawit. Penelitian dilakukan secara eksperimental menggunakan rancangan acak lengkap (RAL) 5 perlakuan, yaitu hormon giberelin sintetik (Kontrol Positif), $0 \mathrm{~g} / \mathrm{l}$ (kontrol negatif), $75 \mathrm{~g} / \mathrm{l}, 150 \mathrm{~g} / \mathrm{l}$, dan $225 \mathrm{~g} / \mathrm{l}$ ekstrak akar eceng gondok, masing-masing yang diulangi sebanyak 5 kali. Hasil penelitian menunjukkan bahwa pemberian ekstrak akar eceng gondok dapat meningkatkan jumlah buah,bobot buah,dan tebal kulit buah tetapi dapat mengurangi jumlah biji dan bobot biji tanaman cabai rawit. Konsentrasi ekstrak akar eceng gondok 225 $\mathrm{g} / \mathrm{l}$ adalah ekstrak akar eceng gondok terbaik yang dapat menghasilkan jumlah buah tanaman rata-rata 331,6 buah, hasil rata-rata bobot buah 326,4 gram per tanaman dengan tebal kulit rata-rata $0,136 \mathrm{~mm}$ per tanaman, rata-rata jumlah biji 11,4 biji dan rata-rata bobot biji 0,1238 gram per cabe rawit . Penelitian ini menyimpulkan bahwa ekstrak akar eceng gondok dapat mengurangi jumlah biji dan meningkatkan bobot tanaman dan hasil panen cabai rawit dengan kosentrasi optimal $225 \mathrm{~g} / \mathrm{l}$.

Kata Kunci: Cabai rawit, hormon giberelin, eceng gondok, hasil panen dan biji cabai rawit.

Abstrac. This research was aimed to explore the effect of water hyacinth root extract (Eichhornia crassipes) on the yields and the amount of chili pepper seeds. The experiment was done using Completely Randomized Design (CDR) of 5 extract treatments, there was synthetic gibberellin hormone (positive control), $0 \mathrm{~g} / \mathrm{l}$ (negative control), $75 \mathrm{~g} / \mathrm{l}, 150 \mathrm{~g} / \mathrm{l}$, and $225 \mathrm{~g} / \mathrm{l}$ of water hyacinth root extract, each was repeated 5 times. The results of this experiment indicate that the application of water hyacinth root extract can increase the amount of fruit, the weight of fruit, and the thickness of fruit peel but decrease the amount and the weight of chili pepper seeds. $225 \mathrm{~g} / 1$ concentration of water hyacinth root extract was the best water hyacinth root extract to produce the amount of the plant with an average 331,6 fruits, the average result of the weight was 326,4 grams per plant with an average thickness of peel 0,136 mm per plant, 11,4 average amount of seeds, and 0,1238 grams average weight of seeds per chili pepper. This experiment concludes that the water hyacinth root extract can decrease the amount of seeds and increase the weight of the plant and the yields of chili pepper.

Keywords: Chili pepper, gibberellin hormone, water hyacinth, yields and chili pepper seeds.
\end{abstract}

\section{PENDAHULUAN}

Cabai Rawit (Capsicum frutescens L) merupakan tanaman holtikultura yang termasuk famili Pontederiaceae. Cabai rawit ini dimanfaatkan sebagai bumbu masakan karena memiliki cita rasa yang pedas dan mampu membangkitkan selera makan bagai penikmat rasa pedas. Sehingga produksi cabai perlu ditingkatkan. Hal ini sesuai data Kementrian Pertanian Republik Indonesia (2017), dimana produksi cabai rawit pada tahun 2015-2016 mencapai 136.818 ton. Permintaan cabai rawit di Indonesia mencapai $4 \mathrm{~kg} / \mathrm{kapita} / \mathrm{tahun}$, kebutuhan tersebut disebabkan oleh banyaknya jumlah pendududk serta banyak industri yang menggunakan bahan baku cabai rawit (Warisno dan Dahana, 2010).

Menurut Pandolfini (2009), menyatakan bahwa konsumsi biji pada buah cabai dapat menyebabkan gangguan pada pencernaan. Jumlah biji sedikit atau tanpa biji dianggap kurang 
menguntungkan karena mengurangi produksi biji atau benih, akan tetapi bermanfaat pada peningkatan kualitas dan produktivitas buah karena dapat memperlambat kematangan pada buah sehingga menambah waktu simpan.

Giberelin merupakan salah satu hormon sintetik bagi pertumbuhan yang berpengaruh terhadap pertumbuhan tanaman dari perkecambahan sampai tanaman dewasa serta berperan pada pembelahan sel dan pembesaran sel (Richard et al., 2001; Matsuoka, 2003; Chudasama dan Thaker, 2007). Menurut Natesh et al., (2005) pemberian hormon giberalin (GA3) pada tahap pembungaan dapat meningkatkan pertumbuhan dan jumlah tanaman cabai. Penyemprotan giberalin 100 ppm meningkatkan jumlah buah dan biji cabai dibandingkan dengan 50 ppm. Hormon giberelin sintetik cukup mahal dan ketersediaanya terbatas, sehingga digunakan alternatif pengganti yaitu hormon giberelin alami yang berasal dari akar eceng gondok.

Eceng Gondok (Eichhornia crassipes) merupakan tanaman air yang mengapung yang memiliki bunga yang menarik. Eceng gondok memiliki kemampuan berkembang biak dengan cepat sehingga dalam waktu yang singkat tanaman ini dapat menutupi permukaan perairan yang luas sehingga menimbulkan dapat menjadi gulma dalam perairan dan menyebankan berkurangnya produktivitas lahan air yaitu mengambil unsur hara air yang dibutuhkan oleh ikan (Wardini, 2008). Tetapi enceng gondok diketahui mempunyai kandungan protein yang antara 12$18 \%$ dan kandungan asam amino yang dapat bermanfaat sebagai fitohormon giberelin (Bayyinatul et al., 2012). Menurut Windarti dan Sopandi (2018), mengungkapkan penggunaan ekstrak akar eceng gondok pada konsentrasi $75 \mathrm{~g} / \mathrm{L}$ berpengaruh terhadap hasil panen baik jumlah dan berat buah cabai rawit serta terbukti dapat menurunkan jumlah biji per buah cabai rawit. Penelitian ini bertujuan untuk mengetahui efek dari pemberian ekstrak akar eceng gondok (Eichhornia crassipes ) terhadap jumlah buah, bobot buah, jumlah bibi, bobot biji, dan tebal kulit buah cabai rawit.

\section{METODE PENELITIAN}

Penelitian ini telah dilaksanakan secara eksperimental di kebun percobaan Program Studi Biologi Universitas PGRI Adi Buana Surabaya. Alat yang digunakan antara lain gelas ukur, hand sprey, timbangan analitik, kertas saring, Total Disolved Solid (TDS), Soil tester, $\mathrm{pH}$ meter. Bahan yang dibutuhkan dalam penelitian ini antara lain benih tanaman cabai rawit (Capsicum frutescens L), akar eceng gondok, pupuk kompos, tanah, Pupuk pintas, Furadan,hormon giberelin sintetik bubuk dan air.

\section{Prosedur Kerja}

\section{Pembuatan Ekstrak Akar Eceng Gondok}

Sebanyak $2250 \mathrm{~g}$ akar eceng gondok segar dibagi menjadi 3 bagian masing-masing berat $375 \mathrm{~g}, 750 \mathrm{~g}, 1125 \mathrm{~g}$. Akar eceng gondok dilumatkan dan disaring menggunakan kertas saring. Filtrat hasil penyaringan dimaserasi dengan perbandingan 1:3,1:7,dan 1:10 aquades. Filtrat yang telah dimaserasi kemudian disimpan pada suhu $4^{\circ} \mathrm{C}$ untuk digunakan sebagai zat pengatur tumbuh alami.

\section{Pelarutan hormon giberelein sintetik}

Pembuatan larutan GA3, sebanyak 1g GA3 dilarutkan dengan menambahkan sedikit alkohol 70\% ke dalam labu takar $1000 \mathrm{ml}$, kemudian ditambahkan akuades sampai volume akhir 
$1000 \mathrm{ml}$, sehingga didapatkan GA3 dengan konsentrasi 1000 ppm sebagai larutan stok. Kemudian untuk mendapatkan GA3 yang diperlukan sesuai perlakuan, maka dilakukan pengenceran dari larutan stok.

\section{Aplikasi pada tanaman}

Penyemprotan dilakukan 3 kali hingga pemanenan. Penyemprotan ekstrak akar eceng gondok dimulai dari satu hari sebelum bunga pertama mekar pada setiap tangkai menggunakan handsprayer. Penyemprotan kedua ekstrak akar eceng gondok dimulai dari bunga yang mekar. Sedangkan ketiga berselang tiga hari dari penyemprotan kedua. Satu unit percobaan terdiri atas lima tanaman. Ketika penyemprotan dilakukan, tandan bunga yang akan disemprot dilindungi dengan plastik mika agar perlakuan tidak mengenai tanaman lain yang tidak dikehendaki.

Penyemprotan dilakukan dengan menyemprotan secara merata sampai semua permukaan bunga pada tandan yang diperlakukan basah. Aplikasi ekstrak akar eceng gondok dilakukan pada pagi hari. Tandan bunga yang telah disemprot diberi label dan diberi tanggal untuk memudahkan dalam penyemprotan berikutnya. Pemberian Ekstrak akar eceng gondok disemprot dengan konsentrasi 0,75 g/l, $150 \mathrm{~g} / \mathrm{l}, 225 \mathrm{~g} / \mathrm{l}$ dan pemberian hormon sitetik dengan konsentrasi dosis yang telah dianjurkan. Pada cabai pemberian 10 atau 20 ppm GA3 menunjukkan pengaruh yang tinggi terhadap pembentukan buah serta meningkatkan hasil.

\section{Analisis statistik}

Semua data hasil pengamatan dianalisis statistikamenggunakan analisis of varian satu arah dengan taraf signifikansi 0,05 . Uji lanjut untuk mengetahui letak perbedaan antara perlakuan dilakukan dengan menggunakan Uji BNT (Beda Nyata Terkecil) dengan taraf signifikansi 0,05.

\section{HASIL DAN PEMBAHASAN}

\section{Jumlah buah tanaman cabai rawit}

Hasil penelitian ini memperlihatkan bahwa pemberian ekstrak akar eceng gondok berpengaruh signifikan $(\mathrm{P}<0,05)$ terhadap jumlah buah tanaman cabai rawit dengan $\mathrm{F}_{\text {hitung }} 1,312$. Jumlah cabai rawit yang diberi perlakuan giberelin sintetik (kontrol positif) 151,8 \pm 5,26 buah dan $0 \mathrm{~g} / \mathrm{l}$ (kontrol negatif) yaitu $122,2 \pm 3,27$ buah signifikan $(\mathrm{P}<0,05)$ lebih rendah dibandingkan dengan perlakuan ekstrak akar eceng gondok 75g/l (209,6 $\pm 5,27$ buah), 150g/l (281,8 \pm 8,07 buah), dan perlakuan ekstrak akar eceng gondok $225 \mathrm{~g} / \mathrm{l}(331,6 \pm 6,10 \mathrm{buah})$. Jumlah buah tanaman cabai rawit dengan perlakuan 75g/l (209,6 \pm 5,27 buah) signifikan $(\mathrm{P}<0,05)$ lebih rendah dibandingkan dengan perlakuan ekstrak eceng gondok $150 \mathrm{~g} / \mathrm{l}(281,8 \pm 8,07$ buah), dan perlakuan ekstrak akar eceng gondok 225g/l (331,6 $\pm 6,10$ buah). Jumlah buah tanaman cabai rawit dengan perlakuan $150 \mathrm{~g} / \mathrm{l}(281,8 \pm 8,07$ buah $)$, signifikan $(\mathrm{P}<0,05)$ lebih rendah dibandingkan dengan perlakuan ekstrak akar eceng gondok 225g/l (331,6 $\pm 6,10$ buah). Jumlah buah cabai rawit tertinggi diperoleh dari perlakuan ekstrak akar eceng gondok $225 \mathrm{~g} / 1$ (Gambar 1).

Hasil penelitian ini mengindikasi bahwa penyemprotan ekstrak akar eceng gondok berpengaruh terhadap jumlah buah pada tanaman cabai rawit. Hasil penelitian yang dilakukan Tiwari at al., (2011) menunjukkan bahwa $\mathrm{GA}_{3}$ yang di perlakukan pada cabai dapat meningkatkan jumlah buah. Akar eceng gondok mengandung $0,18 \%$ hormon giberelin $\left(\mathrm{GA}_{3}\right)$ 
merupakan kelompok fitohormon yang bereperan penting dalam mengkoordinasikan pertumbuhan buah dan pengembangan benih (Musbakri, 1999).

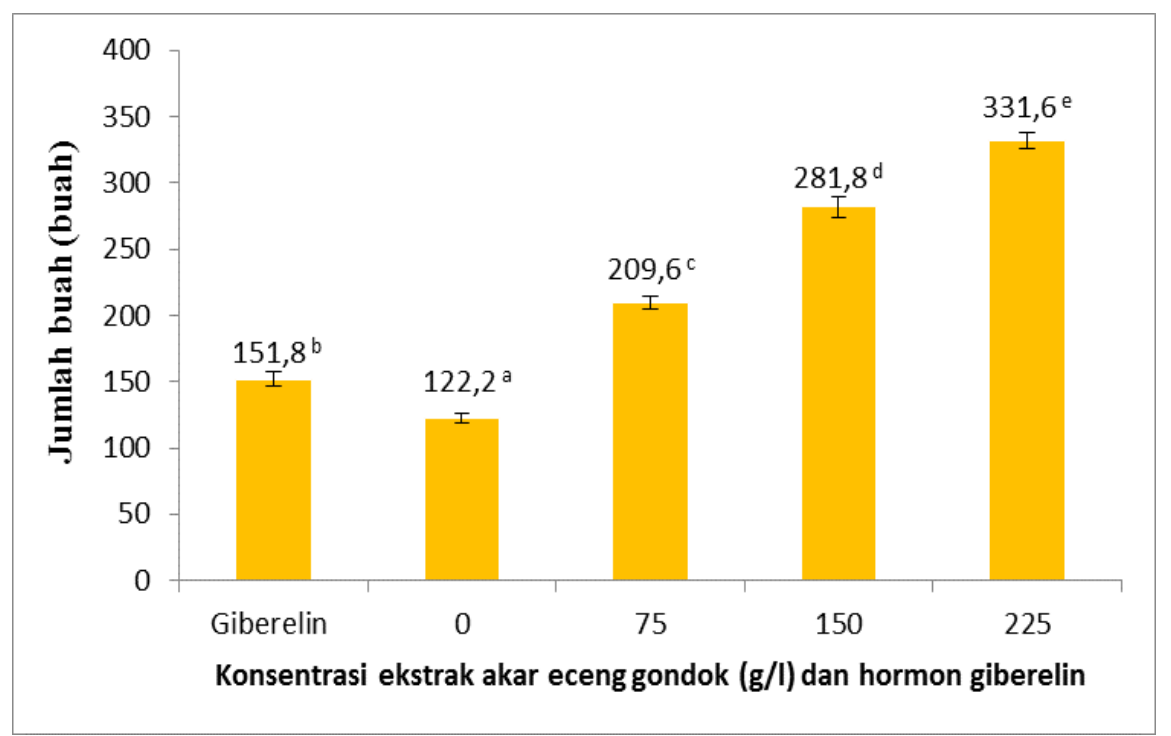

Gambar 1. Jumlah buah tanaman Cabai Rawit (C. frutescents) setelah diberi perlakuan pemberian ekstrak akar Eceng Gondok.

Giberelin membantu dalam pertumbuhan sel batang, daun dan bagian udara lainnya dengan menyebabkan perpanjangan sel, dan peningkatan panjang internodal (Rastogi et al., 2013). Konsentrasi giberelin yang lebih tinggi meningkatkan pertumbuhan tanaman (Bora dan Sarma, 2006). Menurut Permatasari (2016) hormon giberelin pada akar enceng gondok dapat mempercepat proses pembentukan bunga dan jumlah produksi buah cabai mengalami peningkatan. Giberelin berperan dalam pembentukan polihidroksi dari asam sinamat yanitu senyawa yang dapat menghambat kerja enzim IAA oksidase. Giberelin memicu pembentukan enzim $\alpha$-amilase yang berfungsi memecah amilum, hasil dari proses pemecahan amilum tersebut akan dapat digunakan dalam proses respirasi mitokondria, sehingga ATP yang dihasilkan akan digunkan dalam proses pembentangan sel.

\section{Bobot Buah Cabai Rawit}

Hasil penelitian memperlihatkan bahwa pemberian ekstrak akar eceng gondok berpengaruh signifikan $(\mathrm{P}<0,05)$ terhadap bobot buah tanaman cabai rawit dengan $\mathrm{F}_{\text {hitung }} 12,48$. Bobot buah tanaman cabai rawit yang diberi perlakuan giberelin sintetik (kontrol positif) $194.20 \pm 31,28 \mathrm{~g}$ dan 0 g/l (kontrol negatif) yaitu $132 \pm 68,02$ g signifikan $(\mathrm{P}<0,05)$ lebih rendah dibandingkan dengan perlakuan ekstrak akar eceng gondok 75g/l (221,60 \pm 19,92 g), 150g/l (268,80 $\pm 18,41$ g), dan perlakuan ekstrak akar eceng gondok $225 \mathrm{~g} / \mathrm{l}(326,40 \pm 25,076 \mathrm{~g})$.

Bobot buah tanaman cabai rawit dengan perlakuan $75 \mathrm{~g} / 1(221,60 \pm 19,92 \mathrm{~g})$ signifikan $(\mathrm{P}<0,05)$ lebih rendah dibandingkan dengan perlakuan ekstrak akar eceng gondok $150 \mathrm{~g} / \mathrm{l}$ $(268,80 \pm 18,417 \mathrm{~g})$, dan perlakuan ekstrak akar eceng gondok 225g/l (326,40 $\pm 25,076 \mathrm{~g})$. Bobot buah tanaman cabai rawit dengan perlakuan 150g/l $(268,80 \pm 18,41 \mathrm{~g})$, signifikan $(\mathrm{P}<0,05)$ lebih rendah dibandingkan dengan perlakuan ekstrak akar eceng gondok $225 \mathrm{~g} / 1$ $(326,40 \pm 25,07 \mathrm{~g})$. Bobot buah cabai rawit tertinggi diperoleh dari perlakuan ekstrak akar eceng gondok $225 \mathrm{~g} / \mathrm{l}$ (Gambar 2). 
Hasil penelitian ini mengindikasi bahwa penyemprotan ekstrak akar eceng gondok berpengaruh terhadap bobot buah pada tanaman cabai rawit. Tumbuhan eceng gondok terdapat hormon giberelin yang bekerja secara aktif dalam dinding sel sehingga dapat mempercepat pertumbuhan batang, daun dan sistem perakaran. Kandungan eceng gondok memiliki nitrogen yang cukup sehingga dapat meningkatkan sintesis protein untuk pembelahan dan pembesaran sel (Wardini, 2008).

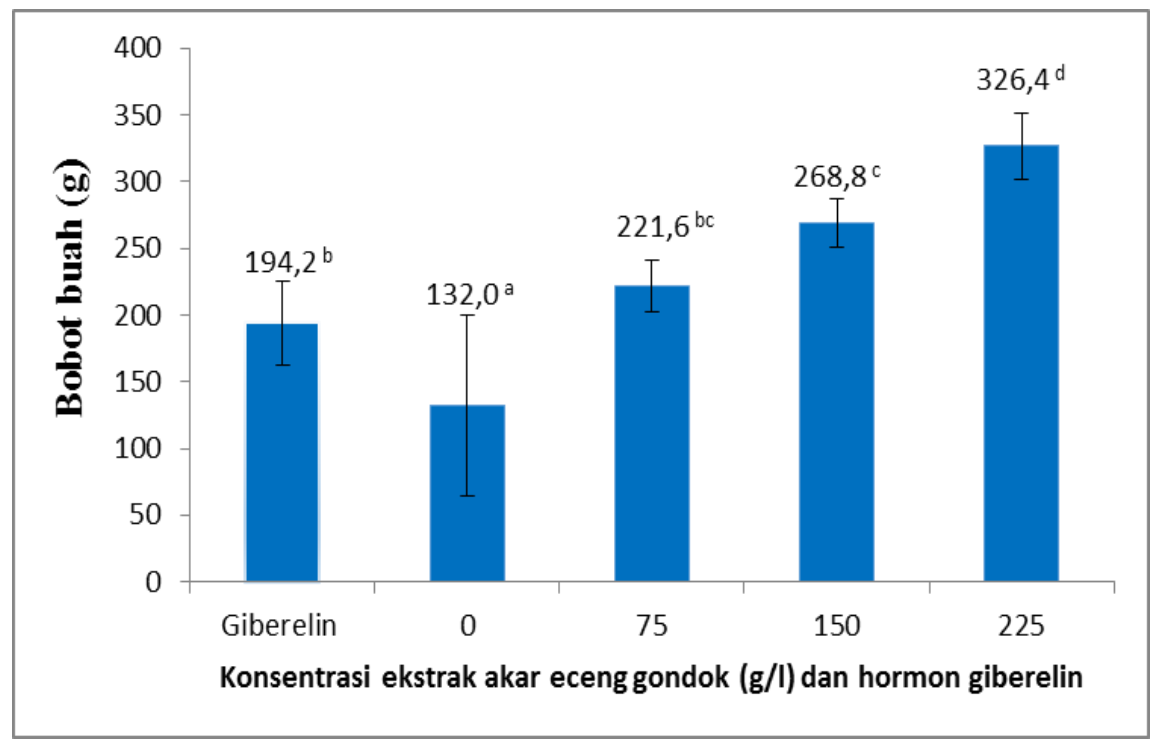

Gambar 2. Bobot buah tanaman Cabai Rawit (C. frutescents) setelah diberi perlakuan pemberian ekstrak akar Eceng Gondok.

Menurut Wijayanto et al., (2012) penelitian yang dilakukan pada semangka bahwa pemberian hormon giberelin memberikan pengaruh yang nyata terhadap berat buah, hal tersebut membuktikan bahwa giberelin memacu proses pertumbuhan tanaman sehingga mempengaruhi produksi tanaman semakin meningkat. Bobot segar tanaman smangka dipengaruhi oleh faktor konsentrasi dan waktu perlakuan giberelin.

Menurut Salisbury dan Ross (1995), pertambahan ukuran sel menghasilkan pertambahan ukuran jaringan, organ dan akhirnya meningkatkan ukuran organ atau bagian-bagian tanaman secara keseluruhan maupun berat atau bobot tanaman tersebut. Peningkatan pembelahan sel menghasilkan jumlah sel yang lebih banyak. Jumlah sel yang meningkat termasuk di dalam jaringan pada daun, memungkinkan terjadinya peningkatan fotosintesis penghasil karbohidrat, yang dapat memengaruhi bobot tanaman. Sedangkan menurut Kartikasari et al., (2016), pemberian Giberelin eksogen saat tanaman dalam fase generatif dapat meningkatkan kapasitas ruang penyimpanan hasil fotosintesa, karena giberelin akan memperbesar ukuran sel jaringan penyimpan yang mengakibatkan semakin banyaknya hasil fotosintesa yang tersimpan, sehingga bobot buah akan tinggi.

\section{Jumlah biji tanaman cabai rawit}

Hasil Penelitian memperlihatkan bahwa pemberian ekstrak akar eceng gondok berpengaruh signifikan $(\mathrm{P}<0,05)$ terhadap jumlah biji tanaman cabai rawit dengan $\mathrm{F}_{\text {hitung }} 321,63$. Jumlah biji tanaman cabai rawit yang diberi perlakuan giberelin sintetik (kontrol positif) 44,00 \pm 
1,580 biji, dan $0 \mathrm{~g} / \mathrm{l}$ (kontrol negatif) yaitu 60,80 $\pm 3,70$ biji signifikan $(\mathrm{P}<0,05)$ lebih tinggi dibandingkan dengan perlakuan ekstrak akar eceng gondok 75g/l (31,60 $\pm 1,67$ biji), 150g/l (23,40 \pm 1,14 biji), dan perlakuan ekstrak akar eceng gondok $225 \mathrm{~g} / 1$ (11,40 $\pm 2,70 \mathrm{biji})$. Jumlah biji cabai rawit dengan perlakuan $75 \mathrm{~g} / 1(222,30 \pm 19,91$ biji $)$ signifikan $(\mathrm{P}<0,05)$ lebih tinggi dibandingkan dengan perlakuan ekstrak akar eceng gondok 150g/l (23,40 \pm 1,14 biji), dan perlakuan ekstrak akar eceng gondok 225g/l (11,40 \pm 2,70 biji) . Jumlah biji tanaman cabai rawit dengan perlakuan $150 \mathrm{~g} / \mathrm{l}(23,40 \pm 1,14$ biji $)$, signifikan $(\mathrm{P}<0,05)$ lebih tinggi dibandingkan dengan perlakuan ekstrak akar eceng gondok 225g/l (11,40 $\pm 2,70$ biji). Jumlah biji tanaman cabai rawit ter rendah diperoleh dari perlakuan ekstrak akar eceng gondok 225g/l (Gambar 3).

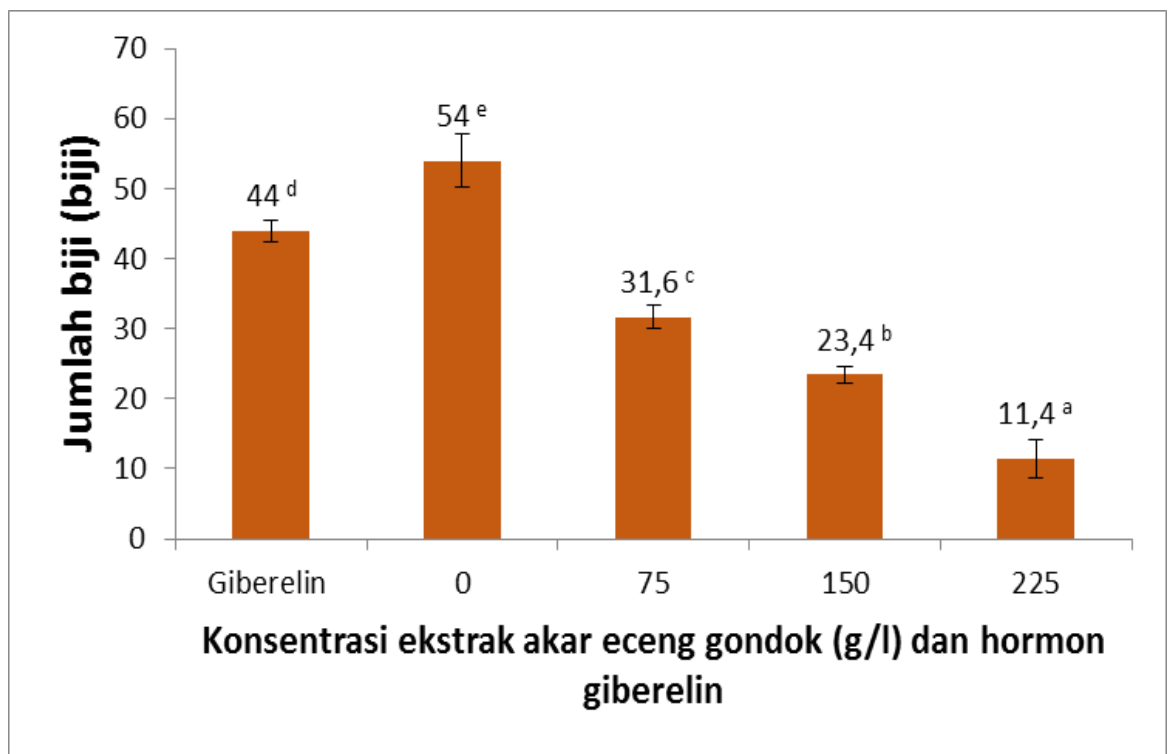

Gambar 3. Jumlah biji tanaman Cabai Rawit (C. frutescents) setelah diberi perlakuan pemberian ekstrak akar Eceng Gondok.

Hasil penelitian ini mengindikasi bahwa penyemprotan ekstrak akar eceng gondok dapat menghambat pertumbuhan biji pada tanaman cabai rawit. Penelitian ini sejalan dengan hasil penelitian Falah et al., (2019) yang menyatakan bahwa pemberian GA3 1.000 ppm dan 1.500 ppm pada buah Zicchini (Cucurbita pepo L.) memberikan hasil yang signifikan dalam menguragi jumlah biji buah. Hasil penelitian tersebut sependapat dengan yang di kemukakan oleh Permatasari, (2016) yaitu giberelin dapat mempengaruhi proses pembentukan biji dan buah saat proses fertilisasi serta biji tidak terbentuk apabila perkembangan embrio tidak terjadi.

Menurut Saptowo (2001), penambahan GA3 memacu tanaman membentuk buah karena GA3 dapat menaikan produksi hormon absisat. Sehingga pada bunga daun dan buah tidak terjadi produksi auksin. Karena proses tidak terjadi, maka GA3 yang disemprotkan dapat menggantikan peranan dari penggunaan auksin pada perkembangan buah dan perkembangan biji sehingga perkembangan biji menjadi terhambat. Partenokarpi dikatakan terjadi,apabila buah terbentuk tanpa diawali proses fertilisasi keberadaan giberelin mampu menggantikan proses fertilisasi. Jadi pemberian hormon giberelin mampu menginduksi terbentuknya buah secara partenokarpi (Pardal, 2001). Molekuler fruit set pada partenokarpi terjadi akibat respon dari induksi yang diakibatkan lonjakan fitohormon serta transportasi yang dapat mengakibatkan tanaman merasakan sinyal dari fitohormon sehingga terdoronglah perkembangan buah partenokarpi (Ruan et al., 2012). 


\section{Bobot biji tanaman cabai rawit}

Hasil Penelitian memperlihatkan bahwa pemberian ekstrak akar eceng gondok berpengaruh signifikan $(\mathrm{P}<0,05)$ terhadap bobot biji tanaman cabai rawit dengan $F_{\text {hitung }} 131,96$. Bobot biji tanaman cabai rawit yang diberi perlakuan giberelin sintetik (kontrol positif) 3,8136 \pm $0,169 \mathrm{~g}$ dan $0 \mathrm{~g} / \mathrm{l}$ (kontrol negatif) yaitu 4,3130 $\pm 0,271 \mathrm{~g}$ signifikan $(\mathrm{P}<0,05)$ lebih tinggi dibandingkan dengan perlakuan ekstrak akar eceng gondok 75g/l (3,0826 $\pm 0,254 \mathrm{~g}), 150 \mathrm{~g} / \mathrm{l}$ $(2,1310 \pm 0,244 \mathrm{~g})$, dan perlakuan ekstrak akar eceng gondok $225 \mathrm{~g} / \mathrm{l}(1,2398 \pm 0,250 \mathrm{~g})$. Bobot biji tanaman cabai rawit dengan perlakuan $75 \mathrm{~g} / \mathrm{l}(3,0826 \pm 0,254 \mathrm{~g})$, signifikan $(\mathrm{P}<0,05)$ lebih tinggi dibandingkan dengan perlakuan ekstrak akar eceng gondok $150 \mathrm{~g} / \mathrm{l}(2,1310 \pm 0,244 \mathrm{~g})$, dan perlakuan ekstrak akar eceng gondok $225 \mathrm{~g} / \mathrm{l}(1,2398 \pm 0,250 \mathrm{~g})$. Bobot biji tanaman cabai rawit dengan perlakuan150g/l $(2,1310 \pm 0,244 \mathrm{~g})$, signifikan $(\mathrm{P}<0,05)$ lebih tinggi dibandingkan dengan perlakuan ekstrak akar eceng gondok 225g/l (1,2398 $\pm 0,250 \mathrm{~g})$. Bobot biji cabai rawit ter rendah diperoleh dari perlakuan ekstrak akar eceng gondok $225 \mathrm{~g} / \mathrm{l}$ (Gambar 4).

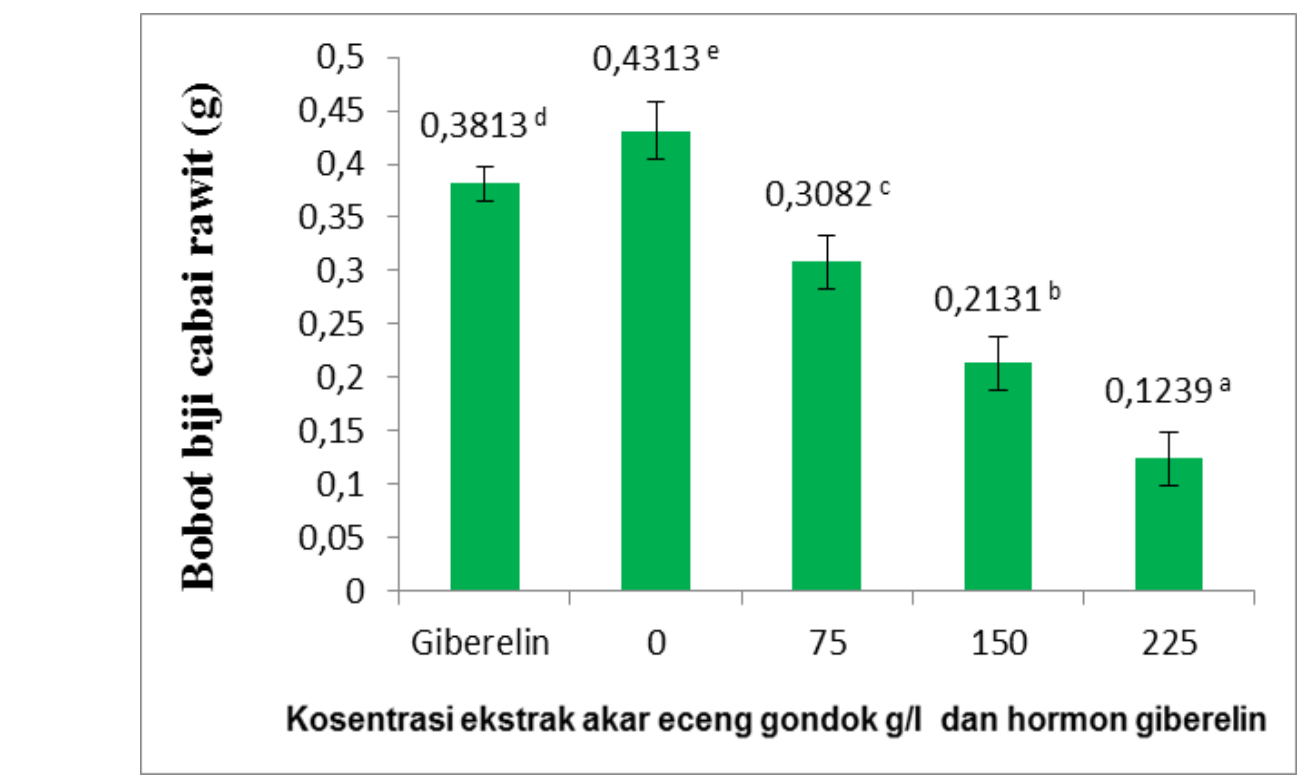

\section{Gambar 4. Bobot biji tanaman Cabai Rawit (C. frutescents) setelah diberi perlakuan} pemberian ekstrak akar Eceng Gondok.

Hasil penelitian ini mengindikasi bahwa penyemprotan ekstrak akar eceng gondok dapat mempengaruhi bobot biji pada tanaman cabai rawit. Peneitian ini sejalan dengan penelitian yang dilakukan oleh Wulandari et al., (2014) pada tanaman mentimun, biji mentimun mengalami penurunan pada aplikasi hormon goiberelin 200 ppm. Menurut Wijayanto et al., (2012) dalam partenokarpi, hormon giberelin mencegah terbentuknya biji dengan menghambat proses fertilisasi. Proses penyerbukan dicegah dengan memotong seluruh bunga jantan yang ada, hal ini untuk meminimalkan kemungkinan terjadinya fertilisasi. Sedangakn menurut Pardal (2001), hormon giberelin akan mencegah sampainya buluh serbuk sari ke celah mikropil pada ovarium dengan merusak dan menghambat perkembangan buluh serbuk sari. Akibatnya, sel sperma tidak dapat bertemu dengan sel telur dan zigot tidak terbentuk. Jika zigot tidak terbentuk, maka perkembangan bakal biji terhenti dan tidak terbentuk biji. 


\section{Tebal kulit buah cabai rawit}

Hasil Penelitian memperlihatkan bahwa pemberian ekstrak akar eceng gondok berpengaruh signifikan $(\mathrm{P}<0,05)$ terhadap tebal kulit tanaman cabai rawit dengan $\mathrm{F}_{\text {hitung }} 16,39$. Tebal kulit tanaman cabai rawit yang diberi perlakuan giberelin sintetik (kontrol positif) $0,136 \pm$ $0,02043 \mathrm{~mm}$ dan $0 \mathrm{~g} / \mathrm{l}$ (kontrol negatif) yaitu $0,112 \pm 0,0075 \mathrm{~mm}$ dan signifikan $(\mathrm{P}<0,05)$ lebih tinggi dibandingkan dengan perlakuan ekstrak akar eceng gondok 75g/l (0,9120 $\pm 0,1645 \mathrm{~mm})$, $150 \mathrm{~g} / \mathrm{l}(0,0822 \pm 0,075 \mathrm{~mm})$, dan perlakuan ekstrak akar eceng gondok $225 \mathrm{~g} / \mathrm{l}(2,251 \pm 0,204$ $\mathrm{mm})$. Tebal kulit buah tanaman cabai rawit dengan perlakuan $75 \mathrm{~g} / 1(0,9120 \pm 0,164 \mathrm{~mm})$ signifikan $(\mathrm{P}<0,05)$ lebih tinggi dibandingkan dengan perlakuan ekstrak akar eceng gondok $150 \mathrm{~g} / \mathrm{l}(1,1200 \pm 0,075 \mathrm{~mm})$, dan perlakuan ekstrak akar eceng gondok $225 \mathrm{~g} / \mathrm{l}(2,251 \pm 0,204$ $\mathrm{mm})$. Tebal kulit tanaman cabai rawit dengan perlakuan $150 \mathrm{~g} / \mathrm{l}(1,1200 \pm 0,075 \mathrm{~mm})$, signifikan $(\mathrm{P}<0,05)$ lebih tinggi dibandingkan dengan $150 \mathrm{~g} / \mathrm{l}(1,1200 \pm 0,075 \mathrm{~mm})$ perlakuan ekstrak akar eceng gondok $225 \mathrm{~g} / \mathrm{l}(2,251 \pm 0,204 \mathrm{~mm})$. Tebal kulit buah cabai rawit tertinggi diperoleh dari perlakuan ekstrak akar eceng gondok 225g/l (Gambar 5).

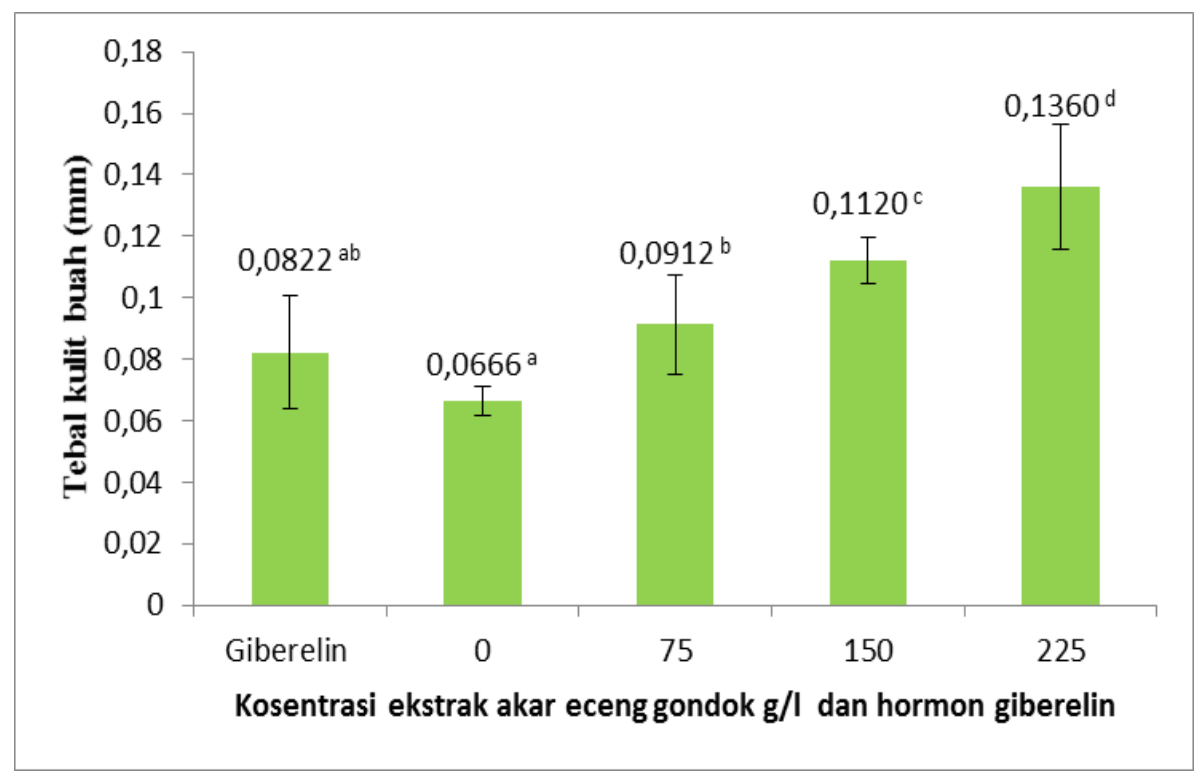

Gambar 5. Tebal kulit tanaman Cabai Rawit (C. frutescents) setelah diberi perlakuan pemberian ekstrak akar Eceng Gondok.

Hasil penelitian ini mengindikasi bahwa penyemprotan ekstrak akar eceng gondok dapat mempengaruhi bobot biji pada tanaman cabai rawit. Menurut Salisbury dan Ross (1995) giberelin akan merangsang terbentuknya enzim aamilase dimana enzim ini akan menghidrolisis pati sehingga kadar gula dalam sel akan naik yang akan menyebabkan air lebih banyak masuk ke sel sehingga sel mengalami pembentangan. Menurut Pardal (2001), dalam perkembangan buah, giberelin akan menginduksi terjadinya pembelahan dan pembentangan pada lapisan perikarpi di bakal buah. Lapisan eksokarpi yang akan berkembang menjadi kulit buah, mesokarpi yang akan mengalami pembelahan dan pembentangan lebih cepat akibat induksi giberelin membentuk daging buah serta endokarpi yang merupakan lapisan terdalam. Enzim $\alpha$-asimilase dapat terbentuk akibat rangsangan dari giberelin, enzim ini berfungsi untuk menhidrolisis pati yang mengakibatkan kadar gula meningkat sehingga air lebih banyak masuk kedalam sel. Banyaknya air yang masuk dalam sel menyebakan sel mengalami pemanjangan (Asra dan Ubaidillah, 2012). 


\section{KESIMPULAN}

Penyemprotan ekstrak akar eceng gondok terbukti dapat meningkatkan jumlah buah, bobot buah dan hasil panen serta terbukti dapat menurunkan jumlah biji dan bobot biji per buah cabai rawit. Konsentrasi terbaik yang diperoleh pada penelitian ini adalah $225 \mathrm{~g} / \mathrm{l}$.

\section{REFERENSI}

Asra, R., dan Ubaidillah. 2012. Pengaruh Konsentrasi Giberelin (GA3) terhadap Nilai Nutrisi Calopogonium caeruleum. Jurnal Ilmu-Ilmu Peternakan, XV(2): 81-85.

Bayyinatul, M., Susilowati, R., dan Kusumastuti, A. 2012. Pemanfaatan Tepung Hasil Fermentasi Eceng Gondok (Eichornia crassipes) sebagai Campuran Pakan Ikan untuk Meningkatan Berat Badan dan Daya Cerna Protein Ikan Nila Merah (Oreochromis sp). Jurnal Ed-Qudwah, 10: 1-9.

Bora, R.K., and Sarma, C.M. 2006. Effect of Gibberellin Acid and Cycocel on Growth, Yield and Protein Content of Pea. Asian Journal of Plant Sciences, 5(2): 324-330.

Chudasama, R.S., and Thaker, V.S. 2007. Relationship Between Gibberellin Acid and Growth Parameters in Developing Seed and Pod of Pigeon Pea. Brazilian Journal of Plant Physiology, 19(1): 43-51.

Falah, R.N., Hamdani, J.S., dan Kusumiyati. 2019. Induksi Partenokarpi dengan $\mathrm{GA}_{3}$ pada Zucchini (Cucurbita pepo L.). Jurnal Kultivasi, 18(3): 983-988.

Kartikasari, O., Aini, N., dan Koesriharti. 2016. Respon Tiga Varietas Tanaman Mentimun (Curcumis sativus L.) Terhadap Aplikasi Zat Pengatur Tumbuh Giberelin (GA3). Jurnal Produksi Tanaman, 4(6): 425-430.

Kementrian Pertanian Republik Indonesia. 2017. Produk cabai rawit pada tahun 2015-2016 mencapai 136.818 ton. http://epublikasi.setjen.pertanian.go.id/. Diakses pada tanggal 15 Januari 2020.

Matsuoka, M. 2003. Giberelin Signaling: How do Plant Cells Respon to GA Signals. Journal of Plant Growth Regulation, 22: 123-125.

Musbakri. 1999. Ekstraksi dan Identifikasi Giberelin Dari Akar Eceng Gondok (Eichhornia crassipes). (Skripsi). Fakultas Teknologi Pertanian. Institut Pertanian Bogor.

Natesh, N., Vyakaranahal, B. S., Shekhargouda, M., and Deshpande, V. K. 2005. Effect of micronutrient and organics on growth, seed yield and quality of chili. Karnataka Journal of Agricultural Sciences, 18 (2): 334-337.

Pandolfini, T. 2009. Seedless Fruit Production by Hormonal Regulation of Fruit Set. Nutrients, 1(2): 168-177.

Pardal, S.J. 2001. Pembentukan Buah Partenokarpi melalui Rekayasa Genetik. http://biogen.litbang.deptan.go.id?terbitan?pdf?agrobio_4_245-49.pdf. Diakses pada tanggal 4 November 2019.

Permatasari, D. A. 2016. Pengaruh Pemberian Hormon Giberelin Terhadap Pertumbuhan Buah Secara Partenokarpi pada Tanaman Tomat Varietas Tombatu F1. LenteraBio:Berkala Ilmiah Biologi, 5(1): 25-31.

Rastogi, RP., Sinha, RP., and Incharoensakdi, A. 2013. Partial characterization, UV-induction and photoprotective function of sunscreen pigment, scytonemin from Rivularia sp. HKAR4. Chemosphere, 93: 1874-1878. 
Richards, D.E., King, K.E, Ait-ali, T., and Harberd, N.P. 2001. How Gibberellin Regulates Plant Growth and Development: A Molecular Genetic Analysis of Gibberellin Signaling. Annual Review of Plant Physiology and Plant Molecular Biology, 52: 67-88.

Ruan, YL., Patrick J.W., Bouzayen, M., Osorio, S., and Fernie, A. R. 2012. Molecular regulation of seed and fruit set. Trends in Plant Science, 17(11): 656-65.

Salisbury, F. B., dan Ross, C. W., 1995. Fisiologi Tumbuhan Jilid 3 Terjemahan Dian R. Lukman dan Sumaryono. ITB. Bandung. 343 hal.

Saptowo, J.P. 2001. Pembentukan buah partenokarpi melalui rekayasa genetik. Buletin Agbio, 4(2): 45-49.

Tiwari, A., Offringa, R., and Heuvelink, E. 2011. Auxin-induced fruit set in Capsicum annuum L. requires downstream gibberellins biosynthesis. Journal of Plant Growth Regulator, 31: $570-578$.

Wardini. 2008. Analisis kandungan Nutrisi pada Eceng Gondok (Eicharnia crassipes). http://digilib.itb.ac.id/gdl.php?mod=browser\&op=read\&id=jbptitbpp-gdlcourse2001-r-

631-sme. Diakses pada tanggal 11 Desember 2019.

Warisno dan Dahana, K. 2010. Peluang Usaha dan Budidaya Cabai. Gramedia Pustaka Utama. Jakarta. 124 hal.

Wijayanto, T., Yani, W. O. R., dan Arsana, M. W. 2012. Respon Hasil dan Jumlah Semangka (Citrullus vulgaris) dengan Aplikasi Hormon Giberelin (GA3). Jurnal Agroteknos, 2(1): 57-62.

Windarti, F., dan Sopandi, T. 2017. Reduksi Jumlah Biji Cabai Rawit (Capsicum frutescents) Dengan Menggunakan Sari Akar Eceng Gondok (Eichhornia crassipes). Stigma,11(2): 4354.

Wulandari, D. C., Rahayu, Y. S., dan Ratnasari, E. 2014. Pengaruh Pemberian Hormon Giberelin terhadap Pembentukan Buah secara Partenokarpi pada Tanaman Mentimun Varietas Mercy. LenteraBio:Berkala Ilmiah Biologi, 3(1): 27-32.

\section{Authors:}

Vivin Andriani, Universitas PGRI Adi Buana Surabaya, Jalan Dukuh Menanggal XII/4 Surabaya, 60234. Jawa Timur. Indonesia, email: v.andriani@unipasby.ac.id

This is an open-access article distributed under the terms of the Creative Commons Attribution License, which permits unrestricted use, distribution and reproduction in any medium, provided the original author and source are credited. (http://creativecommons.org/licenses/by/4.0/).

How to cite this article:

Andriani, V. 2020. Potential extract of root (Eichhornia crassipes) on fruit and Chili seeds (Capsicum frutescents L.). Simbiosa, 9(1): 12-21. Doi. http://dx.doi.org/10.33373/sim-bio.v9i1.2305 